\title{
Modelling the Kinetics of Biogas Production from Mesophilic Anaerobic Co-Digestion of Cow Dung with Plantain Peels
}

\author{
Ganiyu Kayode Latinwo and Samuel Enahoro Agarryb ${ }^{*}$ \\ aDepartment of Chemical Engineering, Biochemical and Chemical Engineering Biotechnology Laboratory, Ladoke Akintola University \\ of Technology, P. M. B. 4000, Ogbomoso, NIGERIA. \\ ${ }^{b}$ Department of Chemical Engineering, Biochemical and Bioenvironmental Engineering Laboratory, Delta State University, P. M. B. 22, \\ Oleh Campus, NIGERIA.
}

\begin{abstract}
This work investigated the effect of plantain peels as co-substrate in the anaerobic digestion of cow dung for efficient and high biogas production. The biogas experiments were carried out in two different $5 \mathrm{~L}$ anaerobic digesters and incubated for 40 days at ambient mesophilic temperatures $\left(28{ }^{\circ} \mathrm{C}\right.$ to $\left.34^{\circ} \mathrm{C}\right)$. The results showed that co-digestion of cow dung with plantain peels as co-substrate reduced start-up time for biogas generation and increased biogas yield by $18 \%$ as compared to cow dung alone. Peak biogas production was obtained for both digesters at $\mathrm{pH}$ of 6.7 and 6.9 as well as temperature of 29 and $30^{\circ} \mathrm{C}$, respectively. Modelling study revealed that exponential plot simulated better in both ascending and descending limb than the linear plot the biogas production rates in biogas production from cow dung co-digested with plantain peels and cow dung alone, respectively. Logistic growth model and modified Gompertz plot showed better correlation of cumulative biogas production than exponential rise to maximum plot. These results show that biogas production can be enhanced efficiently through co-digestion process.
\end{abstract}

Keywords: Anaerobic digestion; Biogas; Cow dung; Co-substrate; Kinetic model; Plantain peels.

Article History : Received Sept 15, 2014 ; Received in revised form Dec 26, 2015; Accepted January 12, 2015; Available online

How to Cite This Article : Latinwo, G.K and Agarry, S.E. (2015). Modelling the Kinetics of Biogas Production from Mesophilic Anaerobic CoDigestion of Cow Dung with Plantain Peels. Int. Journal of Renewable Energy Development, 4(1), 55-63.

http://dx.doi.org/10.14710/ijred.4.1.55-63

\section{Introduction}

The energy consumption worldwide is spontaneously increasing due to rate of industrialization, population growth and state of development in both developed and developing countries in general. However, for many years now, the major source of energy has been the fossil fuel which has lead to global climate change, environmental degradation and human health problems (Sunarso et al., 2012). The incessant rising in price of oil worldwide has created great difficulties for all countries relying on oil for a major proportion of their commercial energy requirements. As a result of these problems and as the increased energy consumption is unavoidable for future economic development; the need to search and provide new alternative energy particularly renewable energy sources is a must. Proper use of biogas system can provide several benefits to the people and the community resulting in resource conservation and environmental protection.

Biogas is a renewable substitute fuel for fossil fuel which is made from nontoxic, biodegradable renewable sources such as animal wastes, agricultural wastes, crop, domestic waste, and industrial waste (Omer et al., 2002). Biogas is produced by anaerobic digestion which is an engineered biochemical process that mineralises organic substrates, e.g. agro-industrial wastes, to methane and carbon dioxide through a series of reactions mediated by a consortium of microorganisms under anaerobic condition (Joaquin et al., 2008; Colussi et al., 2012) and this follows four steps such as hydrolysis, acidogensis, acetogensis and methanogensis (Tiehm et al., 2001). The activity of anaerobic digestion process depends on various factors 
like temperature, $\mathrm{pH}$, and concentration of substrate/nutrients, agitation, and pre-treatment of feedstock, hydraulic retention time and carbon: nitrogen ratio (Yadvika et al., 2004; Sreenivas et al., 2010; Alvydas et al., 2012; Umar et al., 2013). The process is slow and takes 30-50 days for the production which thus results in large volume of the digester and high cost of the system (Mallick et al., 2000). Therefore, there is a need to improve the overall efficiency of anaerobic digestion process in the biogas plants.

Some attempts have been made in the past to increase gas production by stimulating the microbial activity using various biological and chemical additives under different operating conditions. Biological additives include different plants, weeds, crop residues, microbial cultures, etc. (Gunaseelan, 1987), which are naturally available in the surroundings. As such, these are of less significance in terms of their use in the habitat, however if used as additives in biogas plant it could improve its performance significantly. The suitability of an additive is expected to be strongly dependent on the type of substrate (Mallick et al., 2000). An effort to improve biomass conversion efficiency and biogas yield has been conducted by several researchers through improving substrate composition by co-digesting with other substrate (Callaghan et al., 1999; Gelegenis et al., 2007; Lehtomaki et al., 2007; Aremu \& Agarry, 2013). Enhancement of biogas production from cattle dung or animal wastes by co-digesting with crop residues like sugarcane stalk, maize stalks, rice straw, cotton stalks, wheat straw, water hyacinth, onion waste and oil palm fronds (Pound et al., 1981; El Shinnawi et al., 1989; Somayaji \& Khanna, 1994; Sharma, 2002; Iyagba et al., 2009; Ossai, 2013) as well as with liquid waste effluent such as palm oil mill effluent (Umar et al., 2013).

Nevertheless, the search for cost effective and environmentally friendly methods of enhancing biogas generation (i.e. biogas yield) still needs to be further investigated. Plantain constitutes major food crops in Nigeria and as a result, large quantities of waste are often generated from the peels which have become a perennial problem in the environment. Moreover, indiscriminate disposal of these wastes when decomposed may produce noxious gases such as hydrogen sulphide, ammonia etc., which could pose serious environmental hazards. Thus, channeling these peels into biogas production could serve as an efficient way for the management of the wastes while the resulting gas could serve as a source of energy for cooking and lighting for the rural communities. Many workers have studied the reaction kinetics of biogas production and developed kinetic models for the anaerobic digestion process (Nopharatan et al, 2007; Colussi et al., 2012; Wanasolo et al., 2013; Ghatak \& Mahanta, 2014). Ilori et al. (2007) have used both banana and plantain peels alone and in their combined form for biogas production. They did not model the kinetics of biogas production. However, to the best of our knowledge information on the use of plantain peels as co-substrates for stimulation of microbial consortium present in cow dung for biogas production is scarce.

Therefore, the objective of this study is to investigate the effect of biological additive using plantain peels as co-substrate in biogas production from cow dung. The biogas production rates were modeled using linear and exponential equations. In addition, cumulative biogas production was simulated using logistic growth model, exponential rise to maximum and modified Gompertz models, respectively.

\section{Materials and Methods}

\subsection{Sample Collection and Preparation}

Cow dung used as main substrate in this study was obtained from cow sales market in Ogbomoso, Nigeria while plantain peels used as co-substrate were collected from a restaurant in Ogbomoso, Nigeria. The plantain peels were shredded into small pieces and allowed to rot in a plastic bucket for two weeks. The cow dung and shredded plantain peels were sundried for twenty days. Thereafter, they were oven dried at $110^{\circ} \mathrm{C}$ for $10 \mathrm{hrs}$ and mechanically crushed using a mortar and pestle to ensure homogeneity.

Table 1

Characteristics of plantain peels and cow dung (Dry weight basis)

\begin{tabular}{lll}
\hline Parameters & Plantain peels & Cow dung \\
\hline Moisture content (\%) & 10.2 & 8.4 \\
Total solid (\%) & 9.2 & 18.8 \\
Total carbon (\%) & 27.4 & 31.5 \\
Total nitrogen & 1.25 & 2.20 \\
Carbon: Nitrogen ratio & $21.92: 1$ & $14.32: 1$ \\
\hline
\end{tabular}

Table 1 presents the results of the characterization of the lignocellulosic biomass on dry weight basis. Total solid (TS) of plantain peels was found to be $9.2 \%$ and that of cow dung was $18.8 \%$. The C:N ratio of plantain peels was calculated to be 21.92:1, whereas that of cow dung was 14.32:1. Hills \& Roberts (1981) reported that the C:N ratio of feed mixtures between 25 to $30: 1$ and $8 \%$ total solid content of the slurry would give a maximum performance of an anaerobic digester using dairy manure as substrate. Budiyono et al. (2010) stated that total solid content of 7.4 and $9.2 \%$ in cattle dung exhibit the best performance for digestibility while Mahanta et al. (2004) reported that for cattle dung at $35^{\circ} \mathrm{C}$ temperature maximum gas production was obtained with $8 \%$ total solid. This is why the plantain peels was mixed with cow dung and tap water in such a manner 
that the C:N ratio was $28: 1$ ratio and the total solid content of the slurry become $8 \%$.

\subsection{Preparation of the Fermentation Slurry}

Two different fermentation slurry samples T1 (300 g of cow dung $+3450 \mathrm{ml}$ of water) and $\mathrm{T} 2$ (mixture of $150 \mathrm{~g}$ cow dung $+150 \mathrm{~g}$ plantain peels + $3450 \mathrm{ml}$ of water) were prepared according to the method of Ituen et al. (2007). According to the method, total solid (TS) content of the mixture is $8 \%$ of the fermentation slurry.

\subsection{Biogas Experimental Procedure}

Two improvised anaerobic batch digesters each having a capacity of $5 \mathrm{~L}$ with $4 \mathrm{~L}$ working volume was used in this work (Fig. 1). Nitrogen gas was purged through each of the digester to expel oxygen from the digester and make it air tight in order to ensure anaerobic conditions in the headspace of anaerobic digesters (Hassan et al., 2004). Round bottom flask which contained an acidified brine solution were fixed to each of the batch digesters as well as to a conical flask by means of connecting tubes and silicon sealant was applied to ensure no air entrapment. Each of the digesters was charged or seeded with each of the prepared fermentation slurry and was incubated for 30 days at ambient temperature $\left(28 \pm 2^{\circ} \mathrm{C}\right)$. The initial $\mathrm{pH}$ of the fermentation slurry made from cow dung alone and mixture of cow dung and plantain peels was 6.9 and 7.2 , respectively.

The digesters were manually agitated daily for a minute to ensure homogenous dispersion of the constituents of the mixture and to enhance the digestion process by transferring heat throughout the digester as well as to prevent formation of surface crust and scum (Sulaiman et al., 2009). The generated biogas from the digester was collected continuously into a round bottom flask by the down displacement of acidified brine solution; and this was measured daily by reading the volume of acidified brine solution displaced in the round bottom flask which is equal to the volume of gas generated. Also, the temperature and $\mathrm{pH}$ of the fermented slurry in each of the digester was measured at interval of 5 days.

\subsection{Kinetic Modelling of Biogas Generation}

The biogas production kinetics for the description and evaluation of methanogenesis was carried out by fitting the experimental data of biogas production to various kinetic equations. Biogas production rates of cow dung alone and cow dung codigested with plantain was simulated using linear plots. The linear equation of the biogas production rate in the ascending and descending limb can be expressed by Eq. (1) (Kumar et al., 2004; Lo et al., 2010). It is assumed that biogas production rate will increase linearly with increase in time and after reaching a maximum point after sometime it would decrease linearly to zero with increase in time.

$$
y=a+b t
$$

Where, $y$, biogas production rate in $\mathrm{dm}^{3} / \mathrm{gm} / \mathrm{day} ; t$, time in day for digestion; $a\left(\mathrm{dm}^{3} / \mathrm{gm} /\right.$ day $)$ and $b$ $\left(\mathrm{dm}^{3} / \mathrm{gm} /\right.$ day2) are the constants obtained from the intercept and slope of the plot of $y$ vs $t$. For the ascending limb, $b$ is positive and it is negative for the descending limb.

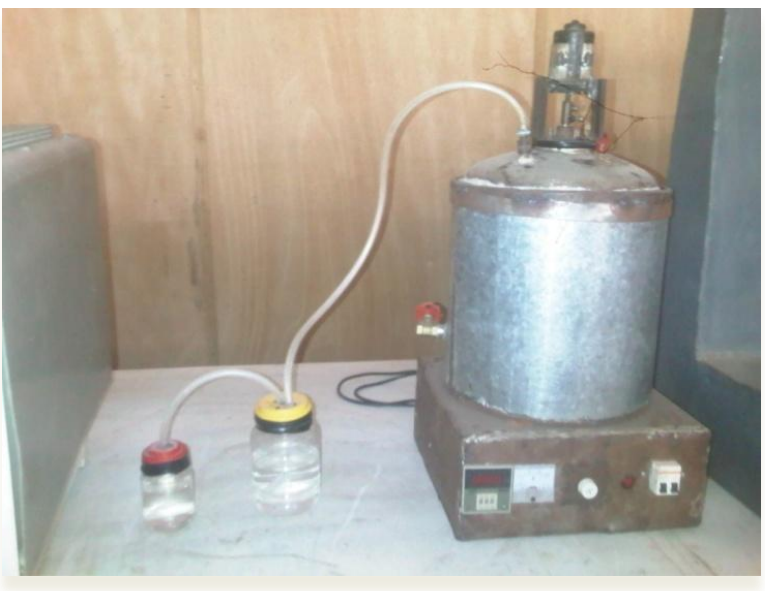

Fig. 1. Experimental set up for biogas production

The exponential plot for the ascending and descending limb can be presented by Eq. (2) (De Gionnis et al., 2009). Here it is assumed that biogas production rate will increase exponentially with increase in time and after reaching the high point it would decrease to zero exponentially with increase in time.

$$
y=a+b \exp (c t)
$$

Where, $y$, biogas production rate in $\mathrm{dm}^{3} / \mathrm{gm} /$ day; $t$, time in day for digestion; $a$ and $b\left(\mathrm{dm}^{3} / \mathrm{gm} /\right.$ day) are the constants; $c=$ constant $\left(\right.$ day $\left.^{-1}\right)$. For the ascending limb, $\mathrm{c}$ is positive and it is negative for the descending limb.

In addition, cumulative biogas production was simulated using logistic kinetic model, exponential rise to maximum and modified Gompertz kinetic model. Logistic kinetic equation is shown in Eq. (3):

$$
C=\frac{a}{1+b \exp (-k t)}
$$

where, $C$, cumulative biogas production $\left(\mathrm{dm}^{3} / \mathrm{gm}\right) ; k$, kinetic rate constant $\left(\right.$ day $\left.^{-1}\right) ; t=$ hydraulic retention time (Days); $a, b$ are the constants. Exponential rise to maximum is presented in Eq. (4) (De Gioannis et al., 2009; Lo et al., 2010): 
Citation: Latinwo, G.K and Agarry, S.E. (2015). Modelling the Kinetics of Biogas Production from Mesophilic Anaerobic Co-Digestion of Cow Dung with Plantain Peels. Int. Journal of Renewable Energy Development, 4(1), 55-63., doi: 10.14710/ijred.4.1.55-63

$\mathrm{P}$ a g e $\mid 58$

$$
C=A(1-\exp (-k t))
$$

Modified Gompertz kinetic model equation is a modified form of the Gompertz equation which is commonly used to simulate the cumulative biogas production (Lo et al., 2010). This model assumes that cumulative biogas production is a function of hydraulic retention time. The modified Gompertz equation can be presented as follows (Budiyono et al., 2010; Yusuf et al., 2011):

$$
P=A \exp \left\{-\exp \left[\frac{r_{m} e}{A}(\lambda-t)+1\right]\right\}
$$

Where, $P$ is the cumulative of the specific biogas production $\left(\mathrm{dm}^{3} / \mathrm{gm}\right), A$ is the biogas production potential $\left(\mathrm{dm}^{3} / \mathrm{gm}\right), \quad r_{m}$ is the maximum biogas production rate $\left(\mathrm{dm}^{3} / \mathrm{gm} /\right.$ day $), \lambda$ is the lag phase period or the minimum time required to produce biogas (day).

\section{Results and Discussion}

\subsection{Biogas Production}

The biogas production rate and accumulation from cow dung (digester D1) and cow dung co-digested with plantain peels (digester D2) is shown in Fig. 2.

It could be seen from Fig. 2 that digesters D1 $(100 \%$ cow dung) and D2 (50\% cow dung $+50 \%$ plantain peels) started the generation of biogas on the 7 th and $5^{\text {th }}$ day of anaerobic digestion, respectively. This observation indicates that biogas production started early for D2 digester and thus a reduction in start-up time as compared to D1 digester. However, the delays in biogas production may probably be due to two factors. Firstly, it may be due to the types of feeding that has been given to the cows which are mainly agricultural crops, such as maize stock. Generally, about $90 \%$ of the dry weight of most plant materials is due to cellulose, hemicellulose and lignin.

The existence of lignin in lignocelluloses creates a protective barrier that stops plant cell destruction by fungi and bacteria for conversion to energy (biogas) unless of course pretreated (Angelidaki \& Ellegaard, 2003). Different pretreatment methods can modify the physical and chemical structure within the lignocellulosic biomass and facilitates hydrolysis rates for conversion to energy (biogas) (Angelidaki \& Ahring, 1993). Secondly, it might be as a result of volatile fatty acids (VFAs) accumulation due to the low biodegradability of cow manure, which resulted in partial inhibition in the digesters. When the volatile fatty acids (VFAs) were consumed, the partial inhibition was overcome and biogas production started. As biogas started generating from digesters D1 $(100 \% \mathrm{CM})$ and
D2 (50\% cow dung $+50 \%$ plantain peels), the results show high biogas production for the first two days.

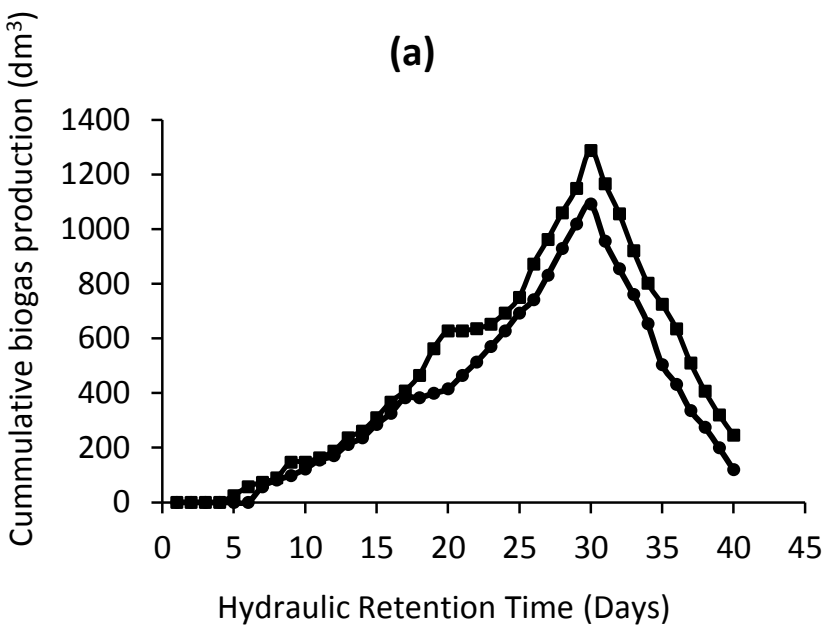

$\rightarrow$ Cow dung $\rightarrow$ Cow dung + Plantain peels

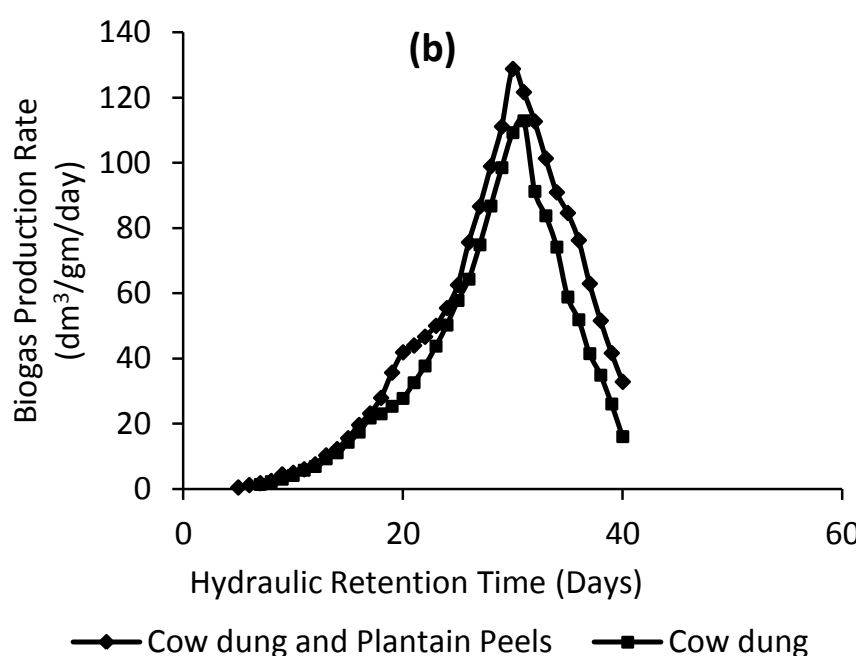

Fig. 2. (a) Cumulative biogas production (b) biogas production rate from cow dung and cow dung co-digested with plantain peels

This might be as a result of acclimatized methane forming bacteria activities as they overcome the protective barrier that prevents plant cell destruction by fungi and bacteria for conversion to energy (biogas) (Angelidaki \& Ellegaard, 2003; Ossai, 2013).

Another plausible explanation for this result is that most of the lignin, cellulose and hemicelluloses content of the substrate was degraded which make it accessible to the micro-organisms for conversion to biogas. The maximum cumulative biogas yield at day 30 was $1092 \mathrm{dm}^{3}$ for D1 digester (100\% cow dung) and $1287.7 \mathrm{dm}^{3}$ for D2 digester $(50 \%$ cow dung $+50 \%$ Plantain peels), respectively. The biogas yields from codigestion are significantly higher than that of monodigestion of cow dung alone. The observed 
phenomenon could be attributable to additional nutrients availability (feedstock composition) and improved carbon-to-nitrogen ratio (C:N) provided by the plantain peels. Similar observations have been reported (Murto et al., 2004; Eze et al., 2007; Iyagba et al., 2009; Ossai, 2013).

This study shows co-digestion in digester D2 to be capable of improving the efficiency of biogas production by $18 \%$ higher than digestion of cow dung alone (D1). However, the cumulative biogas production started to decrease after day 30 in both digesters. Furthermore, it was observed that $\mathrm{pH}$ of the fermentation slurry was changing in the course of biogas production from the anaerobic digestion of cow dung and cow dung co-digested with plantain peels as shown in Fig. 3(a).

$\mathrm{pH}$ is an important factor that affects anaerobic digestion (Rabah et al., 2010). Fig. 3(a) and 3(b) shows that there was a sharp decrease in the $\mathrm{pH}$ of the fermenting medium in the first 5 days of anaerobic digestion in digester 2 (cow dung and plantain peels) and 10 days in digester D1 (cow dung alone), however the decrease was more pronounced with the mixture of cow dung and plantain peels. The observed differential in $\mathrm{pH}$ change may be due to the high volatile solids such as proteins, lipids etc in the cow dung and plantain mixture which were converted more intensely into volatile fatty acid and other acidic metabolites by the activities of aerobes and facultative aerobes that were subsequently metabolized by methanogenic bacteria to generate biomethane (Dennis \& Burke, 2001; Iyagba et al., 2009).

The initial $\mathrm{pH}$ decrease was responsible for low biogas production on the first 5 and 10 days in the digester D2 and digester D1, respectively. Low $\mathrm{pH}$ as been reported to inhibits methanogenic bacteria that are responsible for biogas production (Chynoweth \& Isaacson, 1987; Mahanta et al., 2004). pH value less than 5 or greater than 8 has been reported to rapidly inhibits methanogenesis (Garba \& Sambo, 1992). In addition, it could be seen that high cumulative biogas yield was attained after day 5 (Fig. 3(a)) in digester D2 and day 10 (Fig. 3(b)) in digester D1 respectively as pH started to increase. Similar observations have been reported (Nagamani et al., 1992; Ilaboya et al., 2010).

This observation of increased biogas yield due to increase in $\mathrm{pH}$ may be as a result of increased metabolic activity of the microbial community present in the digester (Lyberatos, 1999). It has been reported that anaerobic bacteria required a natural environment and thus a pH ranging from 6.4-7.2 is needed for optimum biogas production (Garba \& Atiku, 1992; Rabah et al., 2010).

Similarly, marginal variation in temperature $\left(25.5-30^{\circ} \mathrm{C}\right)$ was observed in the course of biogas production from the anaerobic digestion of cow dung and cow dung co-digested with plantain peels as shown in Fig. 4. Fig. 4 shows that biogas production in both digester D1 and D2 took place under mesophilic temperature. Moreover, it is seen from Fig. 3(a) and 3 (b) that the relation between the temperature and gas production rate is proportional because as temperature of fermentation slurry increased the cumulative biogas production also increased.

(a) Cow dung and plantain peels
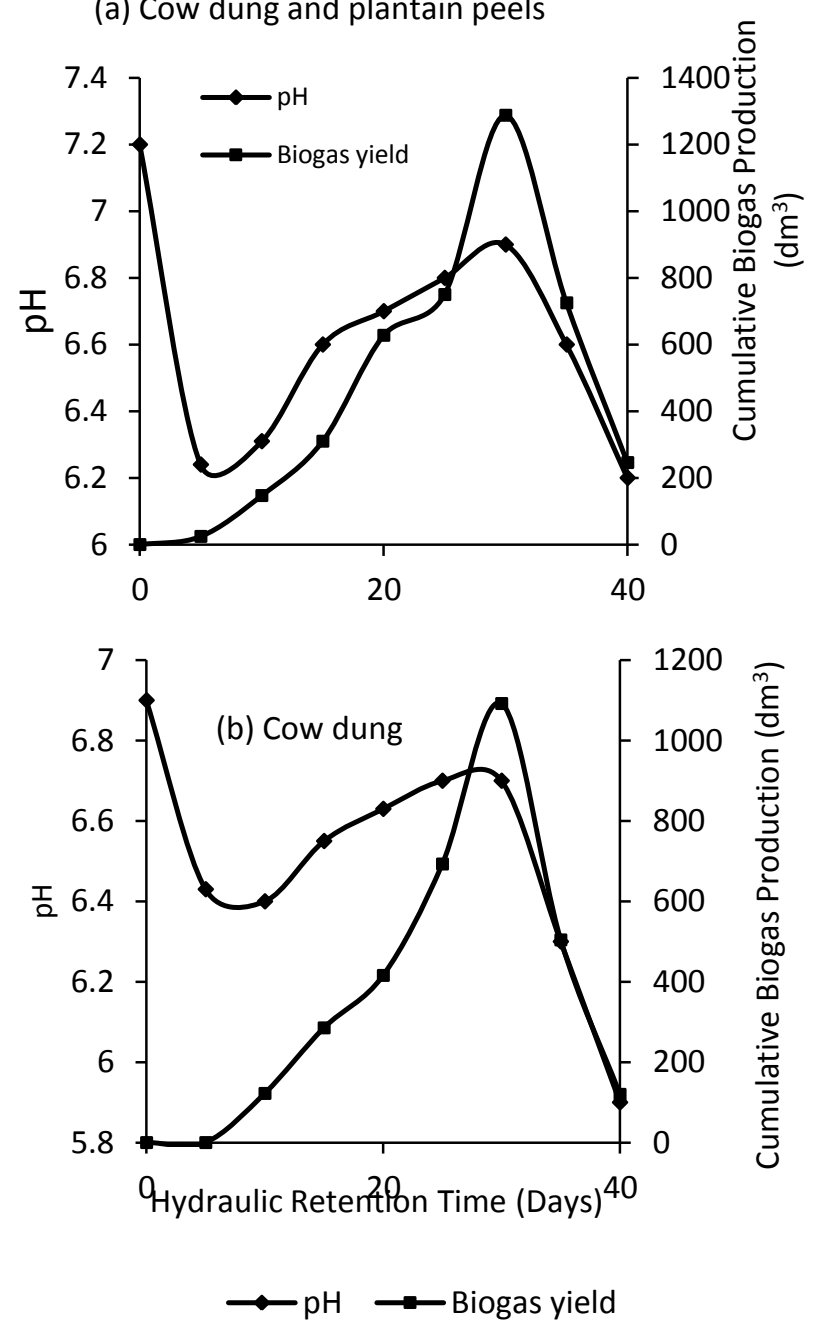

Fig. 3. Changes in $\mathrm{pH}$ and biogas production in (a) digester $\mathrm{D} 2$ that contained cow dung and plantain peels (b) digester D1 that contained cow dung alone

\subsection{Modelling}

Fig. 5(a) and 5(b) shows the linear plots of biogas production rates in the ascending and descending limb from cow dung and cow dung codigested with plantain peels, respectively. Coefficient of determination $\left(R^{2}\right)$ in the ascending and descending limb was 0.8850 and 0.9950 for cow dung alone and 0.8790 and 0.9970 for mixture of cow dung and plantain peels, respectively. 
Citation: Latinwo, G.K and Agarry, S.E. (2015). Modelling the Kinetics of Biogas Production from Mesophilic Anaerobic Co-Digestion of Cow Dung with Plantain Peels. Int. Journal of Renewable Energy Development, 4(1), 55-63., doi: 10.14710/ijred.4.1.55-63

(a) Cow dung and Plantain Peels

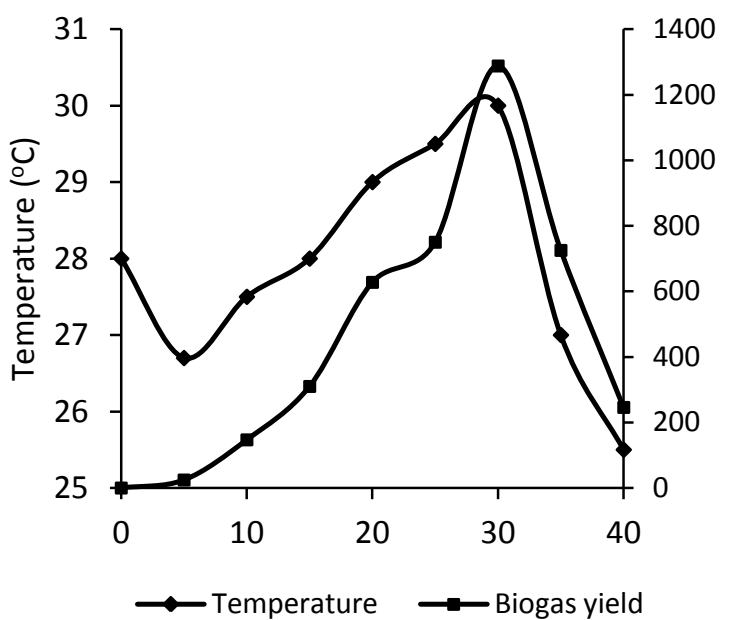

(b) Cow dung

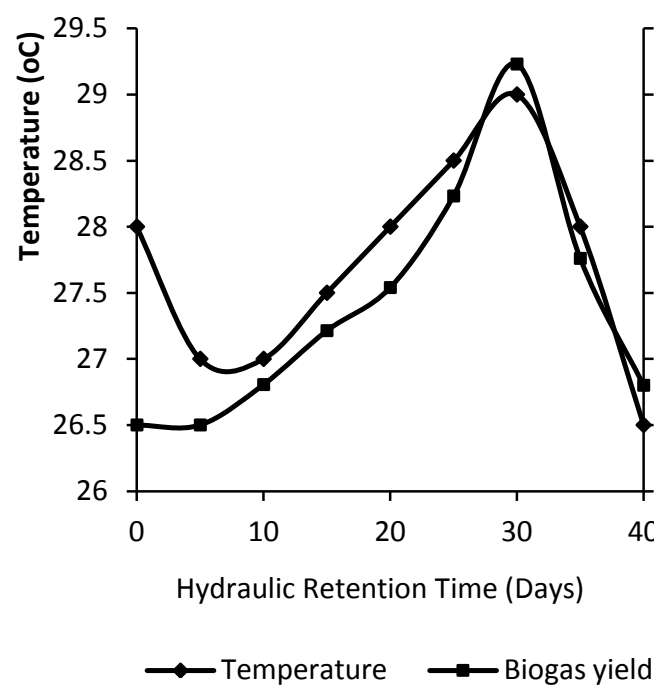

Fig. 4. Changes in temperature and biogas production in (a) digester D2 that contained cow dung and plantain peels (b) digester D1 that contained cow dung alone

Fig. 5(c) and 5(d) shows the exponential plot of biogas production rates in the ascending and descending limb from cow dung alone and cow dung co-digested with plantain peels. The $R^{2}$ in the ascending and descending limb was 0.9988 and 0.9969 for cow dung alone and 0.9951 and 0.9969 for cow dung co-digested with plantain peels, respectively, and these were found to be slightly better simulation than that of the linear regression. Fig. 6(a) and 6(b) shows the experimental cumulative biogas production data as well as the cumulative biogas production simulation using exponential rise to maximum, logistic and modified Gompartz kinetic models for cow dung alone and mixture of cow dung and plantain peels, respectively.
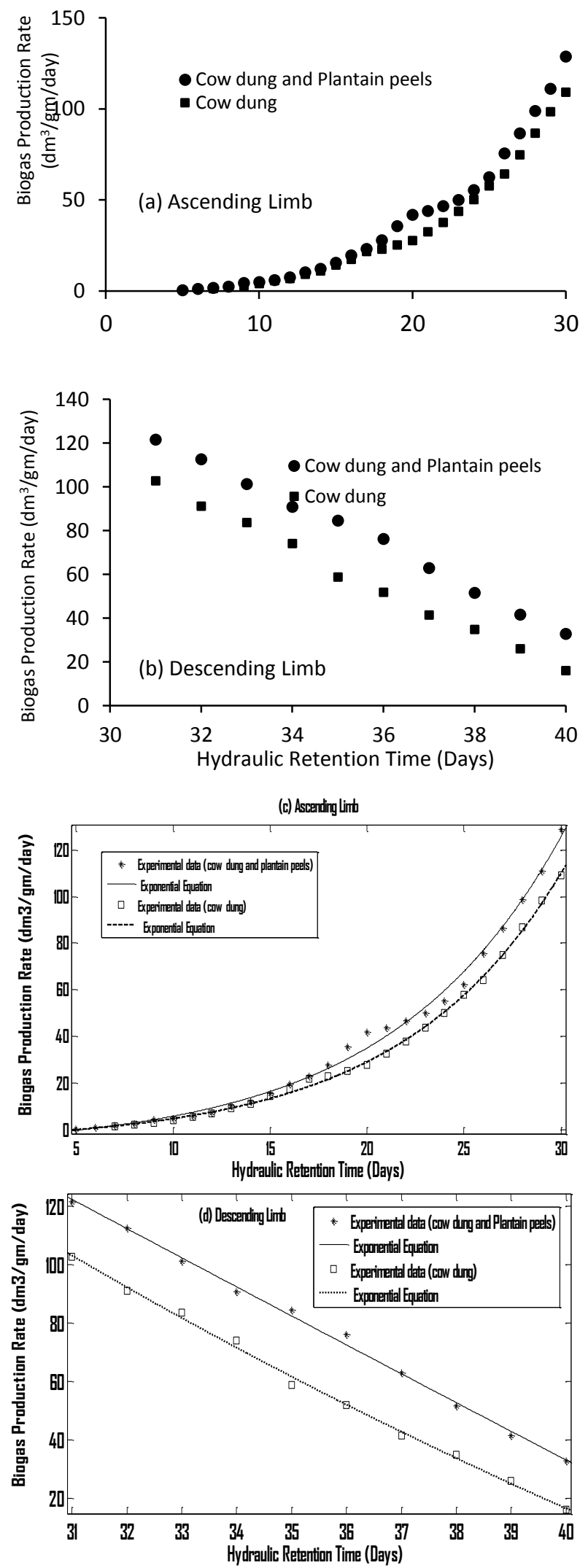

Fig. 5. Linear plots of biogas production rates from cow dung and cow dung co-digested with plantain peels in (a) ascending limb, and (b) descending limb. Exponential plots of biogas production rates from cow dung and cow dung co-digested with plantain peels in (c) ascending limb, and (d) descending limb 
The coefficient of determination was higher for modified Gompertz kinetic model (0.9834-0.9895) and Logistic kinetic model (0.9775-0.9859) than that of the exponential rise to maximum model (0.8543-0.8561) as shown in Table 2 . Thus both the logistic and modified Gompartz kinetic model can be used to simulate biogas production from cow dung alone and its co-digestion with plantain peels, respectively.

In exponential rise to maximum first order kinetic constant ( $k$ ) was found to be in the order of biogas production $\left(1.15 \times 10^{-7} ; 1.247 \times 10^{-7}\right)$ and the cumulative biogas production (A) was in the order of biogas production at $\left(7.616 \times 10^{5} ; 8.26 \times 10^{5} \mathrm{dm}^{3} / \mathrm{gm}\right)$. In modified Gompertz equation, the biogas production potential (A) was found to be in the order of biogas production at $\left(4.733 ; 5.66 \mathrm{dm}^{3} / \mathrm{gm}\right)$ for cow dung alone and mixture of cow dung and plantain peels, respectively. Biogas production rate $(\mu \mathrm{m})$ and lag phase period $(\lambda)$ was found to be 0.0059 and 0.0134 $\mathrm{dm}^{3} / \mathrm{gm} /$ day and 7.178 and 6.110 day for cow dung alone and mixture of cow dung and plantain peels, respectively. In the Logistic kinetic equation, the kinetic rate constant was found to be in the order of biogas production 0.1249 day $^{-1}$ and 0.1766 day $^{-1}$ for cow dung alone and mixture of cow dung and plantain peels, respectively.

\section{(a)}
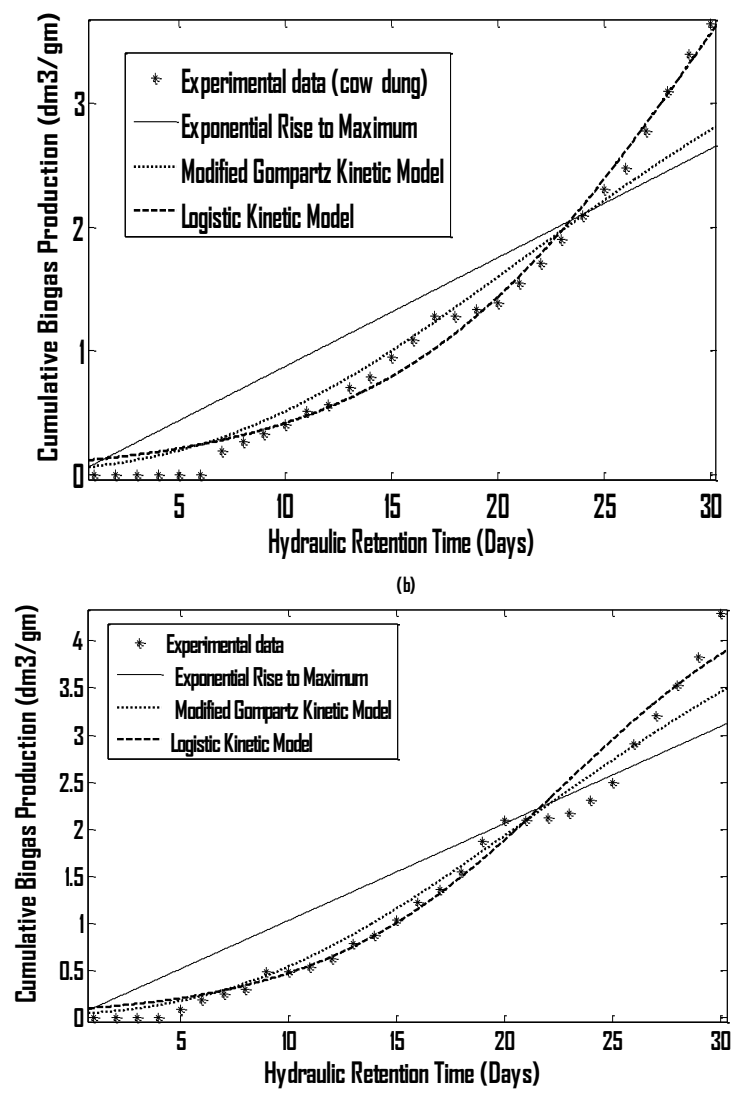

Fig. 6. Kinetic growth models of experimental rise to maximum, modified Gompartz and logistic fitted to the cumulative biogas generation data of (a) cow dung and (b) cow dung and plantain peels
Table 2

Values of model constants and coefficient of determination $\left(R^{2}\right)$ obtained from kinetic models fitted to cumulative biogas production data of cow dung and mixture of cow dung and plantain

\begin{tabular}{|c|c|c|}
\hline Models & Cow Dung & $\begin{array}{l}\text { Cow Dung and } \\
\text { Plantain Peels }\end{array}$ \\
\hline \multicolumn{3}{|l|}{$\begin{array}{l}\text { Exponential } \text { Rise } \\
\text { Maximum }\end{array}$} \\
\hline$A\left(\mathrm{dm}^{3} / \mathrm{gm}\right)$ & $7.616 \times 10^{5}$ & $8.26 \times 10^{5}$ \\
\hline$k\left(\right.$ day $\left.^{-1}\right)$ & $1.15 \times 10^{-7}$ & $1.247 \times 10^{-7}$ \\
\hline$R^{2}$ & 0.8543 & 0.8561 \\
\hline
\end{tabular}

Logistic

$\begin{array}{lcc}a & 10.55 & 4.918 \\ b & 80.15 & 55.12 \\ k\left(\text { day }^{-1}\right) & 0.1249 & 0.1766 \\ R^{2} & 0.9859 & 0.9775\end{array}$

Modified Gompartz

$\begin{array}{ccc}A\left(\mathrm{dm}^{3} / \mathrm{gm}\right) & 4.733 & 5.660 \\ \mu_{m} & 0.0059 & 0.0134 \\ \left(\mathrm{dm}^{3} / \mathrm{gm} / \text { day) }\right. & 7.178 & 6.110 \\ \lambda \text { (day) } & 0.9834 & 0.9895 \\ R^{2} & \end{array}$

\section{Conclusion}

It can be concluded from the anaerobic digestion of cow dung and plantain peels as cosubstrate that the addition of co-substrate has the potential of increasing biogas yield and have a positive influence on early biogas production. $\mathrm{pH}$ range of 6.6 to 6.9 and mesophilic temperature range of 27 to $30{ }^{\circ} \mathrm{C}$ resulted in higher biogas production for both digesters. The maximum cumulative biogas yield was $1092 \mathrm{dm}^{3}$ for digester D1 (100\% cow dung) and $1287.7 \mathrm{dm}^{3}$ for digester D2 (50\% cow dung $+50 \%$ Plantain peels), respectively.

Exponential plot simulated biogas production rate better than that of linear plot both in rising and falling limb. Modified Gompertz plot and Logistic growth plot both had higher correlation than exponential rise to maximum plot for simulating cumulative biogas production. Therefore, arising from the increasing environmental concern and prevailing wastes management crises; optimizing biogas production by co-digestion of agricultural and animal waste represents a viable and sustainable energy option..

\section{References}

Angelidaki, I., \& Ahring, B.K. (1993). Thermophilic digestion of livestock waste: the effect of ammonia. Applied Microbiology Biotechnology, 38, 560-564. 
Citation: Latinwo, G.K and Agarry, S.E. (2015). Modelling the Kinetics of Biogas Production from Mesophilic Anaerobic Co-Digestion of Cow Dung with Plantain Peels. Int. Journal of Renewable Energy Development, 4(1), 55-63., doi: 10.14710/ijred.4.1.55-63

$P$ a g e $\mid 62$

Angelika, I., \& Ellegaard, L. (2003). Co-digestion of manure and organic wastes in centralized biogas plant: status and future trend. Environmental and Resources, Technical University of Denmark.

Aremu, M. O. \& Agarry, S. E. (2013) Enhanced biogas production from poultry droppings using corn-cob and waste paper as cosubstrate. International Journal of Engineering Science and Technology, 5 (2), 247-253.

Budiyono, I N. Widiasa, S. J, \& Sunarso,0. (2010). The Kinetic of Biogas Production Rate from Cattle Manure in Batch Mode. International Journal of Chemical and Biological Engineering, 10(1), 68-75.

Callaghan, F.J., Wase, D.A.J., Thayanithy, K., \& Forster. F.C., (1999) Codigestion of waste organic solids - batch studies. Bioresource Technol., 2, 117-122.

Chynoweth, D. P., Isaacson, R. (1987) Anaerobic Digestion of Biomass Elsevier Applied Science, London.

Colussi, I., Cortesi, A., Gallo, V., Rubesa Fernandez, A. S., Vitanza, R. (2012) Modelling of an anaerobic process producing biogas from winery wastes. Chemical Engineering Transactions, 27, 301 - 306.

De Gioannis G, Muntoni A, Cappai G, \& Milia S. (2009) Landfill gas generation after mechanical biological treatment of municipa solid waste. Estimation of gas generation rate constants. Waste Manage., 29, 1026-1034.

Dennis, A., \& Burke, P. E. (2001). Dairy Waste Anaerobic Digestion Handbook. Environmental Energy Company 6007 Hill street Olympia, W. A 98516. P. 20

Derbal, K., Bencheikh-lehocine, M., Cecchi, F., Meniai, A.H., \& Pavan, P. (2009) Application of the IWA ADM 1 model to simulate anaerobic co-digestion of organic waste with activated sludge in mesophilic condition. Bioresour. Technol., 100, 1539-1543

El Shinnawi, M.M., El Tahawi, B.S., El Houssieni, M., \& Fahmy, S.S. (1989).Changes of organic constituents of crop residues and poultry wastes during fermentation for biogas production. MIRCEN --J. Appl.Microbiol.Biotechnol., 5 (4), 475-486.

Eze, J. I., \& Onwuka, N.D., (2007). Biodegradation of poultry wastes in batch operated plastic biodigesters. Nigeria Journal of Solar Energy, 18, 63-67.

Garba, A. \& Sambo, A. S. (1992). Effect of operating parameter or biogas production rate. Nigerian Journal of solar Energy, 3, 36 44.

Garba, B., \& Atiku, S. (1992). Effect of some operating parameters on Biogas production rate. Nigeria Journal of Renewable Energy, 6 (3), 343-344

Gelegenis, J., Georgakakis, D., Angelidaki, I., \&Mavris, V. (2007) Optimization of biogas production by co-digesting whey with diluted poultry manure. Renewable Energy, 32(13), 2147-2160,

Ghatak, M. D., \& Mahanta, P. (2014) Comparison of kinetic models for biogas production rate from saw dust. International Journal of Research in Engineering and Technology, 03 (07), 248 - 254.

Gunaseelan, V.N., (1987) Parthenium as an additive with cattle manure in biogas production. Biol. Wastes, 21, 1095-2002.

Hassan, M.A., Yacob, S., \& Shirai, Y. (2004). Treatment of palm oil wastewaters. In: Wang, L.K., Hung, Y., Lo, H.H. and Yapijakis, C., editors. Handbook of industrial and hazardous wastes treatment New York. Marcel Dekker, Inc. 719- 36

Hills, D.J., \& Roberts, D. W. (1981) Anaerobic digestion of dairy manure and field crop residues.. Agricultural Wastes, 3, 179-189.

Ilaboya I.R., Asekhame F.F., Ezugwu M.O., Erameh A.A., \& Omofuma F.E . (2010) Studies on biogas generation from agricultural waste; analysis of the effects of alkaline on gas generation. World Applied Sciences Journal, 9 (5), 537-545.

Ilori, M. O, Adebusoye, A, Lawal, A. K, \& Awotiwon, O. A. (2007) Production of biogas from banana and plantain peels. Am. Eurasian J. Sustain. Agric., 1(1), 33-38, 2007

Ituen, E.E, John, N. M, \& Bassey B.E. (2007) Biogas production from organic waste in Akwa Ibom State of Nigeria. Appropriate Technologies for Environmental Protection in the Developing World. Selected Papers from ERTEP 2007, July 17-19, Ghana.

Iyagba, E.I., Mangibo, I.A., \& Mohammad, Y. S. (2009) The study of cow dung as co-substrate with rice husk in biogas production. Scientific Research Essays, 4 (9), 861-868.
Joaquin P. D. (2008). Biogas production from kitchen waste/refuse. Ph.D Thesis, Faculty of Science, Kyambogo University, Uganda.

Kumar, S., Mondal, A.N., Gaikward, S.A., Devotta, S., Singh, R.N. (2004) Qualitative assessment of methane emission inventory from municipal solid waste disposal sites: a case study. Atmos. Environ., 38, 4921-4929.

Lehtomaki, A., Huttunen, S., \& Rintala, J. A. (2007) Laboratory investigations on co-digestion of energy crops and crop residues with cattle manure for methane production: Effect of crop to manure ratio, Resources, Conservation and Recycling, 51, 591-609.

Lo, H.M., Kurniawan, T.A, Sillanpaa, M.E.T, Pai, Y.Y., \& Chiang, C.F. et al., (2010) Modelling biogas production from organic fraction of MSW co-digested with MSWI ashes in anaerobic bioreactors. Bioresources Technology, 101, 6329-6335.

Lyberator, G., \& Skiades, I.V. (1999). Modeling of anaerobic digestion - A Review; Global Nest, 1, 63 -76.

Mahanta, P., Dewan, A., Saha, U.K., \& Kalita, P., (2004) Effect of temperature and total solid concentration on the gas production rate of biogas digester. Journal of Energy in Southern Africa, 15 (4), 112-117

Mallick.J, K. L. Narayana, S. Khuntia, Singh, D., \& Barik. R., (2000) Biogas Generation from Leafy Biomass \& Vegetable Wastes by Application of Ultrasound. Institute of Minerals \& Materials

Murto, M., Björnsson, L., \& Mattiasson, B. (2004). Impact of food industrial waste on anaerobic codigestion of sewage sludge and pig manure. Journal of Environmental Management, 70(2), 101107.

Nagamani, .B., Chitra,V.,. \& Ramasamy, K., (1992). National Symposium on community and institutional Biogas Complexes held at Punjab Agricultural University, Ludhiana, 42-43.

Nopharatana, A., Pullammanappalli, P.C., \& Clarke, W.P. (2007) Kinetics and dynamic modelling of batch anaerobic digestion of municipal solid waste in a stirred reactor. Waste Management, 27, 595-603.

Omer, T.O., \& Fedalla M.O. (2002). Engineering design and Economic Evaluation of a family — sized biogas project in Nigeria. Technovation.

Ossai, 0. S. (2013) Comparative evaluation of qualitative and quantitative biogas production potential of oil palm fronds and co-digestion with cow dung. Journal of Energy Technologies and Policy, 3 (4), $25-33$.

Pound B., Done, F., \& Preston, T.R. (1981). Biogas production from mixtures of cattle slurry and pressed sugar cane stalk, with and without urea. CEDIPCA, CEAGANA, 6, 11-21

Rabah, A. B., Baki, A. S., Hassan, L. G., Musa, M., \& Ibrehim, A. D. (2010) Production of biogas using abattoir waste at different time. Science World Journal, 5, 4

Sharma, D.K., (2002). Studies on availability and utilization of onion storage waste in a rural habitat. Ph.D Thesis, Centre for Rural Development and Technology, Indian Institute of Technology, Delhi, India.

Somayaji, D., \& Khanna, S. (1994) Biomethanation of rice and wheat straw. World Journal of Microbiology and Biotechnology, 10, 521523

Sreenivas, Rao, Retter, R., A., \& Hobbs, P.J. (2010). Effect of Biomass Hydrolysis on Biogas production. Process Biochemistry, 28 (2), 119-123.

Sulaiman, A.M.A., Sherai, Y., Abd-Aziz, S., Tabatabaei, M., Basu, Z., \& Yacob, S. (2009). The effect of mixing on methane production in a semi- Commercial closed digester tank treating palm oil mill effluent. Australian Journal of Basic and Applied Science, 3(3), 1577-1583.

Sunarso, O., Widiasa, S.J., \& Budiyono, I.N. (2012), The Effect of Feed to Inoculums Ratio on Biogas Production Rate from Cattle Manure Using Rumen Fluid as Inoculums. Inter. J. Waste Resour. 2(1), 1-4,

Tiehm, K. N., Zellhorn, M., \& Neis, U. ( 2001), Ultrasonic waste activated sludge disintegration for improving anaerobic stabilization. Wat. Res., 35 (8), 2003- 2009.

Umar, H. S, Firdausi, B. R, Sharifah, R. W. A, \& Fadimtu, M. (2013). Biogas production through Co-digestion of palm oil mill effluent with cow manure. Nigerian Journal of Basic and Applied Science, 21(1), 79-84 
Wanasolo, W., Manyele, S. V., \& Makunza, J. (2013) A kinetic study of anaerobic biodegradation of food and fruit residues during biogas generation using initial rate method. Engineering, 5, 577-586.

Yadvika, S., Sreekrishnan, T.R, Sangeeta, K., \& Vineet, R. (2004). Enhancement of biogas production from solid substrates using different techniques-Bioresource Technology, 1-10.
Yusuf, M.O.L., Debora, A., \& Ogheneruona, D.E. (2011) Ambient temperature kinetic assessment of biogas production from codigestion of horse and cow dung. Res. Agric. Eng., 57(3), 97-104. 